\title{
Journal of Correctional Health Care
}

http://jcx.sagepub.com

Thirty Years After Estelle v. Gamble: A Legal Retrospective

William J. Rold

JOURNAL OF CORRECTIONAL HEALTH CARE 2008; 14; 11

DOI: $10.1177 / 1078345807309616$

The online version of this article can be found at: http://jcx.sagepub.com/cgi/content/abstract/14/1/11

\author{
Published by: \\ (\$)SAGE Publications \\ http://www.sagepublications.com
}

On behalf of:

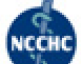

National Commission on Correctional Health Care

Additional services and information for Journal of Correctional Health Care can be found at:

Email Alerts: http://jcx.sagepub.com/cgi/alerts

Subscriptions: http://jcx.sagepub.com/subscriptions

Reprints: http://www.sagepub.com/journalsReprints.nav

Permissions: http://www.sagepub.com/journalsPermissions.nav 
Thirty Years After

Estelle v. Gamble: A Legal Retrospective

\author{
William J. Rold, JD, CCHP-A
}

For more than three decades, beginning with Estelle v. Gamble in 1976, the courts have protected the constitutional right of prisoners to health care. This article explores the historical antecedents of this protection and its present application to modern correctional health care delivery. Focusing on the three basic rights guaranteed by Estelle - the right to access to care, the right to care that is ordered, and the right to a professional medical judgment - the article traces the development of case law in the hundreds of lawsuits that have influenced correctional health care over these years. The article also addresses the "state of mind" component of constitutional liability, the requirement of "serious medical needs" as a predicate to suit, and the impact of privatization on correctional health care delivery. Finally, the article describes the impact of litigation on the promulgation of standards for correctional health care services and on the accreditation of correctional health care systems.

Keywords: correctional health care; Estelle v. Gamble; Eighth Amendment; deliberate indifference

It is but just that the public be required to care for the prisoner, who cannot, by reason of the deprivation of his liberty, care for himself.

-Spicer v. Williamson, Supreme Court of North Carolina, 1926

A s we focus on Estelle v. Gamble (1976) 30 years after the U.S. Supreme Court held that prisoners had a constitutional right to health care, it is important to remember how we got there. To do so, we return to rural North Carolina in 1926.

\title{
The Wounding of Peter Camel and the Common Law Duties of Sheriffs
}

Duplin County Sheriff Williamson's deputy wounded Peter Camel when he returned Mr. Camel's fire while arresting him for armed robbery some 80 years ago. The local doctor

William J. Rold, JD, CCHP-A, is a civil rights attorney in New York City. Formerly with the Prisoners' Rights Project of The Legal Aid Society in New York, he now practices privately and consults on correctional health care and related issues of law, policy, and ethics. He represents the American Bar Association on the board of directors of the National Commission on Correctional Health Care and is a member of the editorial board of the Journal of Correctional Health Care.

The author declares no conflict of interest. For information about JCHC's disclosure policy, please see the Self-Study Exam.

Address correspondence to: William J. Rold, JD, CCHP-A, 30 Vesey Street, Suite 1803, New York, NY 10007; e-mail: wjroldesq@verizon.net. 
told Sheriff Williamson that Mr. Camel's injuries required hospitalization and surgery beyond his skills if he were to survive. Sheriff Williamson took Mr. Camel to Dr. Spicer, a surgeon who owned a hospital in Goldsboro, North Carolina, in the next county. According to the decision, Sheriff Williamson said to Dr. Spicer about Mr. Camel: "He is a human being. He is in my charge ... [D]o the best you can to save him."

After successful surgery, Dr. Spicer sent Sheriff Williamson a bill for his services, which the sheriff presented for payment to the Duplin County Board of Commissioners. The board refused payment, saying that it had not authorized the sheriff to remove the prisoner for care in another county or to incur these expenses. Dr. Spicer sued Sheriff Williamson, who impleaded the Board of Commissioners as a third-party defendant, arguing that the bill was Duplin County's financial responsibility, not his.

These three parties (doctor, sheriff, and county board, each with its own attorney) took this bill dispute to the North Carolina Supreme Court, resulting in the language quoted above. This early decision made three points: (1) It was Sheriff Williamson's duty to arrange for Mr. Camel's medical care, (2) Dr. Spicer was entitled to be paid, and (3) the public (i.e., Duplin County) had to pay. This decision set the stage (and the often highly charged philosophical debate) for everything that has followed: the scope of the duty (Sheriff Williamson took rather extraordinary measures at that time), the "deservingness" of the patient (Mr. Camel had shot a deputy sheriff and was facing the death penalty under North Carolina law), and the power of the courts (forcing Duplin County to pay after its Board of Commissioners had voted no).

Spicer v. Williamson resonated in other early cases. The Supreme Court of Indiana wrote, "We cannot believe that the law intended, where a man was in jail and in need of medical services ... that the county would not be liable for the services thus rendered by a physician under the employ of the jailer having the prisoner in charge" (Lamar v. Board of Commissioners, 1924). Fifty years later, these decisions on the common law duties of sheriffs would converge with the obligation of government under the Eighth Amendment to the U.S. Constitution, as expressed in Estelle v. Gamble.

\section{The Eighth Amendment and the Antecedents of Estelle}

The antecedents of the law's prohibition of excessive punishment date from the time of the Magna Carta, signed by King John at Runnymede at the point of a sword (Granucci, 1969). ${ }^{1}$ Under the rule of Edward I, however, misdemeanors were still punishable by whipping, by mutilation, or by removal of a hand or an ear; felonies, by decapitation. Treason carried particularly harsh punishment: A prisoner could be "drawn, hanged, castrated, disemboweled, burnt, beheaded, and quartered" and "disposed of where His Majesty shall think fit" (Howell, 1814, p. 844). In his Commentaries, Blackstone (1769) wrote that although some punishments, such as "banishment . . . to the American colonies," did not involve physical injury, most were "mixed with some degree of corporal pain" (p. 377).

Before the American Revolution, the Virginia Declaration of Rights, at the behest of George Mason, included a prohibition of "excessive fines" and "cruel and unusual punishments" (Rutland, 1955, pp. 35-36). The original Constitution, however, had no Bill of Rights, a matter of no small concern to the ratifying former British colonies. At the Virginia Convention, Patrick Henry specifically complained of the lack of a prohibition on "cruel and barbarous punishments ... . [and a] Congress ... loose [to] extort confessions by torture" (Elliot, 1881, pp. 447-448).

The First Congress proposed a Bill of Rights, but some argued against including a restriction on punishing criminals: 
Mr. Livermore of New Hampshire: Villains often deserve whipping, and perhaps having their ears cut off ... [A] re we in the future to be prevented from inflicting these punishments because they are cruel? (Annals of Congress, 1789, pp. 782-783)

The minutes show he was outvoted "by a considerable majority" (Annals of Congress, 1789, pp. 782-783). The prohibition against cruel and unusual punishment became part of the Bill of Rights as the Eighth Amendment to the U.S. Constitution in 1791.

Early applications of the Eighth Amendment interpreted it to forbid torture or wanton infliction of suffering, but the courts rarely interfered with prison administration. In 1871, for example, the Virginia Supreme Court of Appeals wrote, "[the prisoner] is for the time being a slave, in a condition of penal servitude to the State, and subject to such laws and regulations as the State may choose to prescribe" (Ruffin v. Commonwealth, 1871).

The Eighth Amendment would lie largely dormant for a century. Indeed, as late as 1963, the Supreme Court of Delaware upheld the use of lashes as punishment, because they were not at the time of William and Mary considered to be "unnecessarily cruel and bordering on outright torture such as breaking on the wheel, public dissection, and the like" (State v. Cannon, 1963).

Historically, the correctional system in the United States has been largely protected from public scrutiny. Prisons were built far from population centers, and courts adopted a "hands-off" doctrine regarding their administration (Procunier v. Martinez, 1963). Early cases in the 1970s, however, revealed horrendous medical conditions in which inmates were used without supervision to perform medical care on their fellows, including pulling teeth, suturing, and performing surgery. Dramatic instances were illustrated in which prisoners died, neglected, covered in maggots, and lying in their own filth (Newman v. Alabama, 1974).

\section{J. W. Gamble and the Texas Prison Farm}

J. W. Gamble was working on a Texas prison farm when a bale of hay fell and injured his back. Mr. Gamble sued Texas's chief prison doctor, the warden, and W. J. Estelle, the director of the state department of corrections, for lack of adequate medical treatment, for denying him a work excuse, and for punishing him for refusing to work when medically unfit. The U.S. District Court dismissed the case for failure to state a claim under the Eighth Amendment, and the case came before the U.S. Supreme Court as Estelle v. Gamble (1976).

By the time of Estelle, the Supreme Court had before it the common law precedents from Spicer and other state courts, statutory authority in some 22 states for the same proposition, development of parallel Eighth Amendment jurisprudence by the lower federal courts, and the standards of numerous organizations, including the U.S. Department of Justice, the National Sheriffs' Association, and the United Nations. It also had its own precedents under the Eighth Amendment that prohibited "torture or a lingering death" (In re Kemmler, 1890) or the "unnecessary and wanton infliction of pain" (Gregg v. Georgia, 1976) and that recognized the "evolving standards of decency that mark the progress of a maturing society" (Trop v. Dulles, 1958). It found that denial of medical care to the incarcerated could, at worst, result in a "lingering death", and, in less serious cases, cause "pain and suffering which no one suggests would serve any penological purpose."

The court developed the standard "deliberate indifference to serious medical needs" to define the Eighth Amendment obligation to provide health care under the Constitution. It has remained largely unchanged for the past 30 years.

Interestingly, Mr. Gamble eventually lost his case. During the 3 months following his injury, he was seen 17 times by various medical personnel for his soft tissue injuries. His complaints were grounded in malpractice, not deliberate indifference. This underscores that 
the standard of liability under the Eighth Amendment is relatively narrow. The Eighth Amendment does not render prison officials or staff liable in federal cases for malpractice or accidents, nor does it resolve professional disputes about the best choice of treatment. It does, however, protect three basic rights.

\section{Estelle's Three Basic Rights}

In the hundreds of published cases following Estelle, three basic rights have emerged - the right to access to care, the right to care that is ordered, and the right to a professional medical judgment (Rold, 2001). The failure of correctional officials to honor these rights has resulted in protracted litigation, the awarding of damages and attorneys' fees, and the issuance of injunctions regarding the delivery of health care services.

Access to care. The right to access to care is fundamental. When access is denied or delayed, the health staff does not know which patients need immediate attention and which patients need care that can wait. "A well-monitored and well-run access system is the best way to protect prisoners from unnecessary harm and suffering and, concomitantly, to protect prison officials from liability for denying access to needed medical care” (Winner, 1981).

In June 1987, a federal court placed New York's Bedford Hills Correctional Facility for Women under a comprehensive court order after it found a "total breakdown in the administration of the dental clinic," resulting in the inmates "suffering from pain, loss of teeth, discomfort, weight loss, and infection" (Dean v. Coughlin, 1985a). At trial, the prison's dentist testified that it often took him 3 days to see all the patients on 1 day's emergency list and that he was still working on February's emergency list in May. With respect to routine care, the evidence showed that more than 300 requests for appointments had been submitted to the dental clinic over the last year, but nothing had been done with them. They were kept, unacknowledged, in a gauze box. The court's order required same-day evaluation of emergency requests and routine dental appointments within 1 week (Dean v. Coughlin, 1986).

All institutions, of whatever size, must have the capacity to cope with emergencies and to provide for sick call. Access to specialists and to inpatient hospital treatment, where warranted by the patient's condition, is also guaranteed by the Eighth Amendment.

Ordered care. Generally, courts assume that care would not have been ordered if it were not needed. Thus, once a health care professional orders treatment for a serious condition, the courts will protect, as a matter of constitutional law, the patient's right to receive that treatment without undue delay. The easiest way for an institution to lose a lawsuit is to fail to provide inmate patients with the care that its own staff has ordered.

In Martinez v. Mancusi (1970), which the Supreme Court cited with approval in Estelle, a constitutional claim was stated when a prisoner was refused his prescribed medication and his leg surgery was rendered unsuccessful by requiring him to stand for the count despite contrary instructions from his surgeon. Estelle thus imposes a legal duty on administrative and custodial staff to honor medical orders and extends liability to those who interfere with ordered care.

To ensure that care that is ordered is, in fact, delivered, courts have required the treating physician to specify the time for a test or examination within which a specialist consultation or hospital admission must occur. In turn, once the doctor has determined the appropriate time limits, the court will direct that the order be honored by other medical and correctional staff.

Professional judgment. The adjudication of constitutional claims is not the business of secondguessing health care professionals. In enforcing the right to a professional medical judgment, 
the courts will not determine which of two equally efficacious treatment modalities should be chosen. Rather, the courts seek to "ensure that decisions concerning the nature and timing of medical care are made by medical personnel, using equipment designed for medical use, in locations conducive to medical functions, and for reasons that are purely medical" (Neisser, 1977).

The actual decisions of prison medical personnel are at issue under Estelle only when they are not actually medical in nature, or they are so extreme or abusive as to be completely outside the range of professional medical judgment. In Williams v. Vincent (1974), also cited with approval by the Supreme Court in Estelle, an inmate whose ear had been severed presented himself for medical treatment. The physician's choice of the "easier and less efficacious treatment" of throwing away the prisoner's ear and stitching the stump was attributed to deliberate indifference rather than the exercise of professional judgment. Numerous other examples are found in the case law: Thomas v. Pate, 1974 (injection of penicillin with knowledge that prisoner was allergic and refusal of doctor to treat the allergic reaction); Rogers v. Evans, 1986 (psychiatrist avoided prisoner after complaints were made about treatment); Jones $v$. Johnson, 1986 (denial of treatment for painful condition for budgetary rather than medical reason).

The right to professional judgment thus places an outer, constitutional, limit on medical discretion, by ensuring that it is, in fact, exercised in making decisions in individual cases. By requiring professional judgment, the federal courts have not only protected the sphere of discretion surrounding medical practitioners' diagnostic and treatment decisions but have also enhanced them in the unique environment in which they are undertaken.

\section{Medicine and the Correctional Milieu}

As the Supreme Court has recognized, "[p]risons and jails are inherently coercive institutions that for security reasons exercise nearly total control over their residents' lives and the activities within their confines" (West v. Atkins, 1988). Prison health care professionals work in what has been described as a "medically alien setting" (Wishart \& Dubler, 1983) that has a tendency to "subjugat[e] professional standards to administrative consideration in the decision-making process" (Lichtenstein, 1981), fostering in professionals a "lack [of] autonomy which is vital for successful performance" (Engel, 1969).

In an institution, "general schedules that strictly regulate work, exercise, and diet necessarily collide with individual medical orders for treatment" (Neisser, 1977). The practitioner will weigh a patient's medical need for special clothing, a special diet, an extra shower, a permit for a cane, or more frequent access to exercise equipment against the administrative difficulty of deviating from the normal rules and the effect granting such an exception may have on other patients who might seek similar treatment or the institution's willingness to accede to such exceptions in the future.

More generally, inmates cannot self-treat minor ailments such as headaches, upset stomachs, or colds, nor may they just stay in bed when they feel ill. Common items such as aspirin, dental floss, antacids, and Band-Aids typically must be obtained from the prison's medical staff. Thus, prisoners must seek medical assistance even if all they need is an overthe-counter remedy or a day in bed (Todaro $v$. Ward, 1977). Such prison rules greatly enlarge the routine demands on medical staff and influence the handling of sick call (Twaddle, 1976) and speciality referrals (Lessenger \& Bader, 1984).

The institutional environment produces continual pressure to tailor the choice and quantity of medical treatment to demands of institutional security, productivity, discipline, and administrative convenience. Such institutional influence means that health staff will be 
under constant pressure not to exercise the discretionary functions nominally delegated to them. "The risk of retaliation for the medical professional who dares to intrude on the turf of the deputy warden for operations is very real" (Nathan, 1985).

The effect of all of this is destructive of the professional relationship between provider and patient and engenders distrust. "No individual, however skilled and compassionate a doctor, can maintain a normal doctor-patient relationship with a man whom the next day he may acquiesce in subjecting to solitary confinement" (Brazier, 1982).

Because the doctor-patient relationship in a correctional facility is imposed by the state, the dissatisfied patient (or doctor, for that matter) is not free to select a different provider (or patient). This absence of freedom of choice removes the "competitive quality controls" of the marketplace that normally influence the behavior of physicians (Neisser, 1977).

Other safeguards that reinforce appropriate norms of sound practice also tend to be weaker in corrections. Collegiality with large numbers of fellow doctors is often less common because, historically, prison health care has been isolated from the larger medical community, and prisons are often located in remote rural places far from large tertiary care centers and medical campuses. The recognition that the isolation of prisons calls for public scrutiny can be traced to early statutes such as the English Coroner's Acts of 1887 and 1926, widely replicated throughout the United States, which required investigation by inquest of "all sudden, violent or unnatural deaths, and the deaths of people in prison," whether "natural or not" (Thurston, 1962).

\section{"Serious Medical Needs"}

The Constitution requires that correctional officials provide medical care only for "serious medical needs." Thus, even if a practitioner is "deliberately indifferent," it does not matter legally in a federal case unless the medical need is "serious." Generally, a medical need is serious if it "has been diagnosed by a physician as mandating treatment or . . . is so obvious that even a lay person would easily recognize the necessity for a doctor's attention" (Duran v. Anaya, 1986; Ramos v. Lamm, 1980). Conditions are also considered to be serious if they "cause pain, discomfort, or threat to good health" (Dean v. Coughlin, 1985b). A condition need not be life threatening to be deemed serious, and many treatment plans that are labeled "elective" nevertheless are deemed serious within the meaning of Estelle.

In general, courts consider three factors in determining whether correctional officials are being deliberately indifferent to serious medical needs: (1) the amenability of the patient's condition to treatment, (2) the consequences to the patient if treatment does not occur, and (3) the likelihood of a favorable outcome. Within this mix, the court may also consider the length of the patient's anticipated incarceration. It is one thing to decline the provision of dentures or an artificial limb to an inmate with a 3-day jail sentence. It is quite another to withhold such adjuncts to a patient serving 20 years to life (Rold, 1997).

\section{State of Mind}

Although the constitutional standard does not require that an express intent to inflict pain be shown (Wilson v. Seiter, 1991), it does include an inquiry into the defendant's state of mind for a "subjective" showing of "deliberate indifference." It is not enough that the defendant should have known or ought to have understood the danger to the inmate. The defendant must know of and disregard a substantial risk (Farmer v. Brennan, 1994). Such knowledge, however, can be inferred from the surrounding facts where the failure to respond to a clear risk is reckless. 
In Farmer v. Brennan (1994), a frail, transsexual inmate was raped by other inmates after placement by prison officials in general population at the federal maximum security prison in Terre Haute, Indiana. The Supreme Court found that the obviousness of the risk of an assault to this potential victim could establish a defendant's deliberate indifference. In health care, failure to provide access to care, denial of care that is ordered, or the absence of professional medical judgment in the delivery of medical services will usually satisfy the "subjective test" of Farmer, where the unaddressed medical needs are serious.

Because the "state of mind" element of the federal civil rights claim explores the defendant's subjective thinking while rendering care (or when allegedly withholding it), evidence normally protected from disclosure in a garden-variety state medical malpractice case may be ordered to be produced in a federal civil rights lawsuit. "Defendants cannot defend on the ground that they acted in good faith (and therefore lack the subjective state of mind necessary for liability) while at the same time refusing access to evidence as to what their state of mind was" (Rold, 2006). Thus, peer review material and mortality reports may be key evidence in assessing, for example, the state of mind of health care supervisors in dealing with a problem subordinate or a deficiency in systems or resources.

In Agster v. Maricopa County (2005), the court ordered production of a contractual provider's death review of an inmate who expired after placement in a jail's restraint chair, writing: "In these circumstances, it is peculiarly important that the public have access to the assessment by peers of the care provided." Peer reviews of deaths of mental patients who expired in a state institution were also ordered disclosed by the court in New York. ${ }^{2}$

\section{The Impact of Managed Care and "Contracting Out": West v. Atkins}

Estelle was decided before the advent of modern notions of HMOs, managed care, and "contracting out" for medical services. The impact of these developments on correctional health care would reach the Supreme Court in 1988. Again, North Carolina was center stage.

Quincy West was an inmate whose Achilles tendon was repaired by Dr. Atkins, an orthopedic surgeon under contract with the North Carolina Department of Corrections. Mr. West's lawsuit claiming that Dr. Atkins's care was so deficient as to constitute deliberate indifference was dismissed by the lower federal courts because Dr. Atkins was an independent contractor, not a state employee. This case was of considerably greater moment than the Achilles tendon job that prompted it or the quality of Dr. Atkins's care: If corrections could avoid Estelle liability simply by contracting out, the body of law developed since Estelle was gravely at risk.

The Supreme Court ruled that Dr. Atkins could be sued under the Eighth Amendment (West v. Atkins, 1989). Two important principles emerge from West and its progeny: First, private contractors to state and local governments who provide services to prisoners are "state actors" for purposes of the Eighth Amendment; second, the governments who hire them also remain liable for failing to provide constitutionally adequate care.

\section{The Correctional Health Care World After Estelle}

It is not possible to imagine the correctional health care landscape today without Estelle. In a 1972 study of American jails, for example, the American Medical Association ${ }^{3}$ found that

$25 \%$ had no medical facilities whatsoever,

$65.5 \%$ had first aid as the only medical care available,

$28 \%$ had no regular sick call, and

$11.4 \%$ did not have a physician on call. 
The absence of rudimentary health care for prisoners at the time of Estelle and in its early wake prompted the creation of the National Commission on Correctional Health Care (NCCHC) out of the American Medical Association and the promulgation of national standards and accreditation.

Cases following Estelle are replete with accounts of inadequate and inhumane health care systems that have been elevated to constitutional acceptability through federal court litigation. ${ }^{4}$ In short, medical care for American prisoners "vastly improved. In no small part this trend may be attributed to the Supreme Court's decision in Estelle v. Gamble" (Jacobs, 1983, p. 29). By 1995, at least 40 states, plus the District of Columbia, Puerto Rico, and the Virgin Islands, were under court order or consent decree regarding conditions, including health care, in either their entire system or in major facilities (American Civil Liberties Union, 1995).

More generally, the prospect of litigation has encouraged corrections officials to improve medical services without waiting to be sued and has contributed to the further development of professional standards. Recognition of adherence to standards such as those of NCCHC has resulted in accreditation. Nearly one in five inmates, or more than 400,000, in virtually every state and territory, is in a facility that is accredited by NCCHC. The Commission's accreditation program has nearly doubled in participation in the last 20 years. ${ }^{5}$

A substantial body of literature has developed since Estelle, including treatises-see Puisis (2006) and Anno (2001). There are now also numerous periodicals devoted specifically to correctional health care. ${ }^{6}$

Presently, there are 2.2 million Americans incarcerated on any given day (Bureau of Justice Statistics, 2006), up from approximately 330,000 in 1980 (Bureau of Justice Statistics, 2005); and the states expended more than $\$ 3.3$ billion in 2001 money on inmate medical care (Bureau of Justice Statistics, 2004). The vast majority of prisoners will be released during their lifetimes (Hughes \& Wilson, 2003) and their medical and mental health needs while incarcerated far exceed those found in the general population. ${ }^{7}$

Among the recommendations of the Report of the Commission on Safety and Abuse in America's Prisons is that Congress "change the Medicaid and Medicare rules so that correctional facilities can receive federal funds to help cover the costs of providing health care to eligible prisoners" (Gibbons \& Katzenbach, 2006). Federal law prohibits federal reimbursement under the Medicaid program for care and services provided to individuals who are "inmate[s] of a public institution" (42 U.S.C.). The Estelle obligation thus remains one of the largest unfunded federal mandates in state and local budgets.

\section{Conclusion}

"No serious student of American correctional history can deny that litigation has provided the impetus for reform of medical practice in prisons and jails" (Nathan, 1985). Estelle, for someone like me, who was struggling to practice in this area at the time, was a breathtaking decision. This constitutionalization of correctional health care remains the most significant Supreme Court decision in this area 30 years later. J. W. Gamble and his Texas farm accident was the same trumpet for the Eighth Amendment right to health care for prisoners as was Gideon and his Florida store robbery for the Sixth Amendment right to counsel for criminal defendants. As resources become increasingly scarce and government officials are constantly faced with doing more with less, it can be taken as some comfort that the courts remain steadfast as a last resort for a safety net for prisoner patients and for their providers, and that Estelle is still good law. 


\section{Notes}

1. The Magna Carta (1215) devoted three chapters (20-22) to this subject.

2. Protection \& Advocacy for Persons with Disabilities v. Mental Health \& Addiction Services, 448 F.3d 119 (2d Cir. 2006), reported in New York Law Journal, May 16, 2006. For a critique of such disclosure, see Paris (2006).

3. See Steinwald et al. (1973), details summarized in Correctional Health Care Report, 6, 1 (2004); see also U.S. Comptroller General (December 22, 1978), Report to the Congress: A federal strategy is needed to help improve medical and dental care in prisons and jails.

4. Compare Battle v. Anderson, 376 F. Supp. 402, 415-6 (E.D. Okla. 1974) with Battle v. Anderson, 788 F.2d 1421, 1426-7 (10th Cir. 1986); Jones v. Wittenberg, 330 F. Supp. 707, 718 (N.D. Ohio 1971), aff'd sub nom. Jones v. Metzer, 456 F.2d 854 (6th Cir. 1972) with Jones v. Wittenberg, 509 F. Supp. 653, 684-87 (N.D. Ohio 1980); Lightfoot v. Walker, 486 F. Supp. 504 (S.D. Ill. 1980) with Lightfoot v. Walker, 619 F. Supp. 1481, 1489 (S.D. Ill. 1985), aff'd, 826 F.2d 516 (7th Cir. 1987); Finney v. Arkansas Board of Correction, 505 F.2d 194, 202-04 (8th Cir. 1974), subsequent order aff'd sub nom. Hutto v. Finney, 437 U.S. 678 (1978) with Finney v. Mabry, 546 F. Supp. 628, 631 (E.D. Ark. 1982).

5. Compare National Commission on Correctional Health Care, Report of the Accreditation Committee (2006) with Report of the Accreditation Committee (1987).

6. See Journal of Correctional Health Care (National Commission on Correctional Health Care), Correctional Health Care Report (Civic Research Institute), CorrectCare (National Commission on Correctional Health Care), and CorHealth Journal (American Correctional Health Services Association).

7. See, generally, National Commission on Correctional Health Care, The health status of soonto-be released inmates: A report to Congress (2004).

\section{References}

42 U.S.C. $\$ 1396 \mathrm{~d}(\mathrm{a}) ; 42$ C.F.R. $\$ 435.1008$.

Agster v. Maricopa County, 406 F.3d 1091 (9th Cir. 2005).

American Civil Liberties Union. (1995). Status report. Washington, DC: Author.

Annals of Congress. (1789).

Anno, B. J. (2001). Correctional health care: Guidelines for the management of an adequate delivery system. Chicago: National Commission on Correctional Health Care.

Blackstone, W. (1769). Commentaries on the laws of England. Oxford, UK: Clarendon Press.

Brazier, M. (1982). Prison doctors and their involuntary patients. Public Law, 282-300.

Bureau of Justice Statistics. (2004). State prison expenditures 2001. Washington, DC: U.S. Department of Justice, Office of Justice Programs.

Bureau of Justice Statistics. (2005). Prisoners under state or federal jurisdiction 1977-2004. Washington, DC: U.S. Department of Justice, Office of Justice Programs.

Bureau of Justice Statistics. (2006). Prison and jail inmates at midyear 2005. Washington, DC: U.S. Department of Justice, Office of Justice Programs.

Dean v. Coughlin, 623 F. Supp. 392 (S.D.N.Y. 1985a).

Dean v. Coughlin, 623 F. Supp. 392, 404 (S.D.N.Y. 1985b).

Dean v. Coughlin, 633 F. Supp. 308, injunction vacated on other grounds, 804 F.2d 207 (2d Cir. 1986).

Duran v. Anaya, 642 F. Supp. 510,524 (D.N.M. 1986).

Elliot, J. (1881). The debates in the several state conventions on the adoption of the federal constitution (2nd ed.).

Engel, G. V. (1969). The effect of bureaucracy on the professional autonomy of the physician. Journal of Health and Social Behavior, 10, 30-41.

Estelle v. Gamble, 429 U.S. 97 (1976).

Farmer v. Brennan, 511 U.S. 825 (1994). 
Gibbons, J. J., \& Katzenbach, N. B. (2006). Confronting confinement. Washington, DC: Commission on Safety and Abuse in America's Prisons.

Granucci, A. F. (1969). "Nor cruel and unusual punishments inflicted": The original meaning. California Law Review, 57, 839-865.

Gregg v. Georgia, 428 U.S. 153, 173 (1976).

Howell, T. (1814). A complete collection of state trials.

Hughes, T., \& Wilson, D. J. (2003). Reentry trends in the United States. Washington, DC: Department of Justice, Office of Justice Programs, Bureau of Justice Statistics.

In re Kemmler, 136 U.S. 436, 447 (1890).

Jacobs, J. B. (1983). New perspectives on prisons and imprisonment. Ithaca, NY: Cornell University Press.

Jones v. Johnson, 781 F.2d 769 (9th Cir. 1986).

Lamar v. Board of Commissioners, 30 N.E. 912 (Ind. 1924).

Lessenger \& Bader. (1984). Medical consultation for correctional institutions. Journal of Prison and Jail Health, 4, 96.

Lichtenstein, R. (1981). A classification of prison health systems based on their bureaucratic attributes. Journal of Prison and Jail Health, 3, 40-56.

Martinez v. Mancusi, 443 F.2d 1192 (2d Cir. 1970).

Nathan, V. (1985). Guest editorial. Journal of Prison and Jail Health, 5, 3-12.

Neisser, E. (1977). Is there a doctor in the joint? The search for constitutional standards for prison health care. Virginia Law Review, 63, 921-973.

Newman v. Alabama, 503 F.2d 1320 (5th Cir. 1974).

Paris, J. (2006). Correctional peer review loses privilege. Correctional Health Care Report, 7, 17.

Procunier v. Martinez, 416 U.S. 405, 416 (1974); see also Note, Beyond the ken of the courts: A critique of the judicial refusal to review the complaints of convicts, 72 Yale Law Journal, 506 (1963).

Puisis, M. (Ed.). (2006). Clinical practice in correctional medicine (2nd ed.). St. Louis, MO: Mosby.

Ramos v. Lamm, 639 F.2d 559, 575 (10th Cir. 1980).

Rogers v. Evans, 792 F.2d 1052 (11th Cir. 1986).

Rold, W. (1997). An examination of medical necessity and the law. CorrectCare, 11(1), 6-14.

Rold, W. (2001). Legal considerations in the delivery of health care services in prisons and jails. In B. J. Anno (Ed.), Correctional health care: Guidelines for an adequate delivery system (pp. 43-65). Chicago: National Commission on Correctional Health Care.

Rold, W. (2006). A civil rights lawyer looks at peer review disclosure. Correctional Health Care Report, 7(49), 59-60.

Ruffin v. Commonwealth, 62 Va. (21 Gratt) 790 (1871).

Rutland, R. (1955). The birth of the Bill of Rights 1776-1791. Chapel Hill: University of North Carolina Press.

Spicer v. Williamson, 132 S.E. 291, 293 (N.C. 1926).

State v. Cannon, 55 Del. 587, 591, 190 A.2d 514, 515-6 (Del. 1963).

Steinwald et al. (1973). Medical care in U.S. jails: A 1972 survey. Chicago: American Medical Association.

Thomas v. Pate, 493 F.2d 151 (7th Cir. 1974).

Thurston. (1962). The coroner's limitations. Medical-Legal Journal, 30, 110.

Todaro v. Ward, 431 F. Supp. 1129 (S.D.N.Y.), aff'd, 565 F.2d 48 (2d Cir. 1977).

Trop v. Dulles, 356 U.S. 86, 101 (1958).

Twaddle, A. C. (1976). Utilization of medical services by a captive population: An analysis of sick call in a state prison. Journal of Health and Social Behavior, 17, 236-248.

West v. Atkins, 487 U.S. 42 (1988).

West v. Atkins, 487 U.S. 42 (1989).

Williams v. Vincent, 508 F.2d 541 (2d Cir. 1974).

Wilson v. Seiter, 501 U.S. 294 (1991).

Winner, E. (1981). An introduction to the constitutional law of prison medical care. Journal of Prison and Jail Health, 1, 67-84.

Wishart, M. D., \& Dubler, N. N. (1983). Health care in prisons, jails and detention centers: Some legal and ethical dilemmas. New York: Montefiore Medical Center. 